\title{
QUALITY IMPLICATIONS ON THE BUSINESS OF LOGISTIC COMPANIES
}

\author{
Miloš Vasić* \\ University of Belgrade, Faculty of Mechanical Engineering, Belgrade, Serbia \\ Aleksandra Potkonjak \\ Lagermax AED DOO, Šimanovci, Serbia \\ Darko Stanojević \\ University of Belgrade, Faculty of Mechanical Engineering, Belgrade, Serbia \\ Miloš Dimitrijević \\ Institute for research and design in commerce and industry, Belgrade, Serbia
}

In turbulent commerce which characterizes all its branches, quality represents one of the rare tools that for companies provide possibility for diversification and separation from (dis)loyal competition. Neither Lagermax AED nor market of logistic services represent an exception. Company - Lagermax AED, as a leader in Serbian market, has recognized world trends and started with implementation of international ISO standards in own business. The aim of this paper is to indicate to some issues that Lagermax has during the process of standard implementation, as well as all benefits that company has and will have in near future, which would come from generally accepted and confirmed management system.

Key words: Commerce, Management system, ISO 9001, Lagermax AED, Logistic companies

\section{INTRODUCTION}

Constant need on the market for implementation of some of developed management systems, with no doubt, occurs because of many benefits that management systems bring. Turbulent contemporary commerce almost doesn't questions implementation of some management systems, considering the constant increase of clients' requirements from the point of their satisfaction. Many world examples, as well as in the Republic of Serbia, have proved that management systems present one of the most successful tools for fulfillment of constant increase in clients' requirements in aspect of quality.

Thus, ISO standards and their requirements that are necessary to be fulfilled for successful implementation of a management system bring with them benefits, such as, above all, organized system of business operations, which provides backward traceability and possibility to discover issues in their work operations.

Implementation brings significant cost reduction, as well as increase in company value from $2-3 \%$, and the fact that we currently have over 450 companies in China, which has the most developed commerce in the world, that have implemented some of ISO standards, is not for surprising. [01, 04]
As well as some other areas of commerce, implementation of management system also finds its place in large market of logistic services. One of the representative examples for that is implementation of management system in large logistic distribution center such as Lagermax AED doo, representative company in Serbia which is one of the leading companies for providing services for international transport and logistics for Serbian market and which is the part of Lagermax Group situated in Salzburg. Central office of Lagermax AED doo is placed in Belgrade-Simanovci and as a part of Lagermax Group, company operates in all regional centers: Novi Sad, Nis, Cacak, where it has distribution logistic centers. Lagermax AED doo, representative company of Lagermax Group in Serbia, has recognized the need for management systems implementation, and in the first place implementation of quality management system (ISO standard 9001:2008), environmental management system (standard ISO 14001:2004), occupational health and safety management system (OHSAS 18001:2007), HACCP system and IFS logistic system. The paper analyzes, interprets and indicates the benefits and problems specific to this case, in terms of the implementation of a management system: quality management system.. 


\section{PRINCIPLES OF IMPLEMENTATION OF MANAGEMENT SYSTEMS}

Principle of implementation of almost all management systems is based on Deming cycle (Figure 1), i.e. PDCA cycle (Plan-Do-Check-Act), which represents management tool for control and improvment of operation processes.

PLAN - Implementation of management system, through implementation of policy, goals, procedures etc.;

DO - Implementation and application of policy and procedures which were defined in previous phase;

CHECK - Monitor and review of management system, through evaluation, and when applicable, measuring of performances regarding defined policy and goals;

ACT - Maintain and improve of management system, through corrective and preventive actions in aim to provide constant improvment of management system; [03]

\section{QUALITY MANAGEMENT SYSTEM (ISO 9001)}

The aim of quality management system implementation is not to achieve the highest existing level of quality, as some organizations that want to implement ISO 9001 think. Quality management system and its requirements are such that they continuously and organizingly initiate the need for frequent reviews and improvement, and also after implementation which enables organizations to do same activity in the same way, thus final achieved result is always the same. In other words, organizations in that way achieve their own specific quality level of providing services, thus the clients always know what they can expect, i.e. what product/service they will get.

The best picture of successful implementation of quality management system ISO 9001 in one organization is achieved business ambience which brings continuous improvement of work operations.

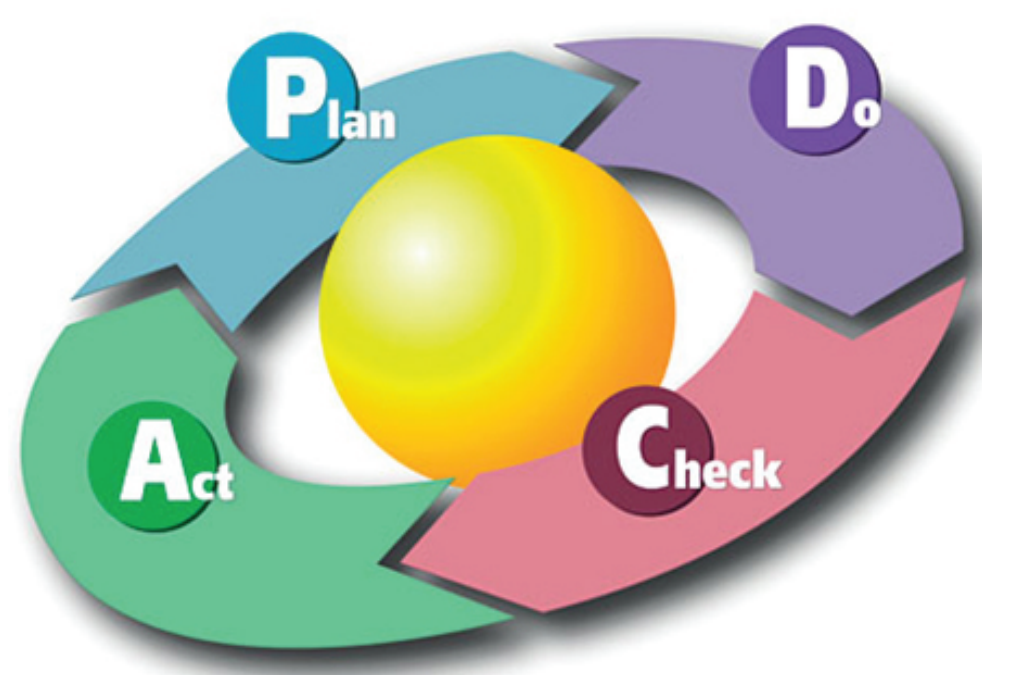

Figure 1: Deming cycle (PDCA cycle)

Figure 2 shows the way of application of Deming cycle i.e. PDCA cycle. Figure shows the principle of constant quality increase. For providing continuous improvement it is necessary to continuously use of PDCA cycle. In that way, level of quality of provided services are timely increased. Increase of awareness about importance of ISO 9001 standard implementation is one of the key activities for establishing such environment. Frequently, employees see implementation of quality management system as a set of documents. But, with adequate application of those documents, as requirements of ISO 9001 stan- dard define, it can be seen clearly that quality management system indeed represents good tools for improvement of business activities and provides necessary information for top management. [01]

With use of process approach, standard ISO 9001 identifies processes which are important for organizations business activities, and also those relations through so-called process maps.

In this way, processes are ranked by relevance and form the business objectives of the organization, with the participation of all employees, reach the expected level of customer satisfaction. 


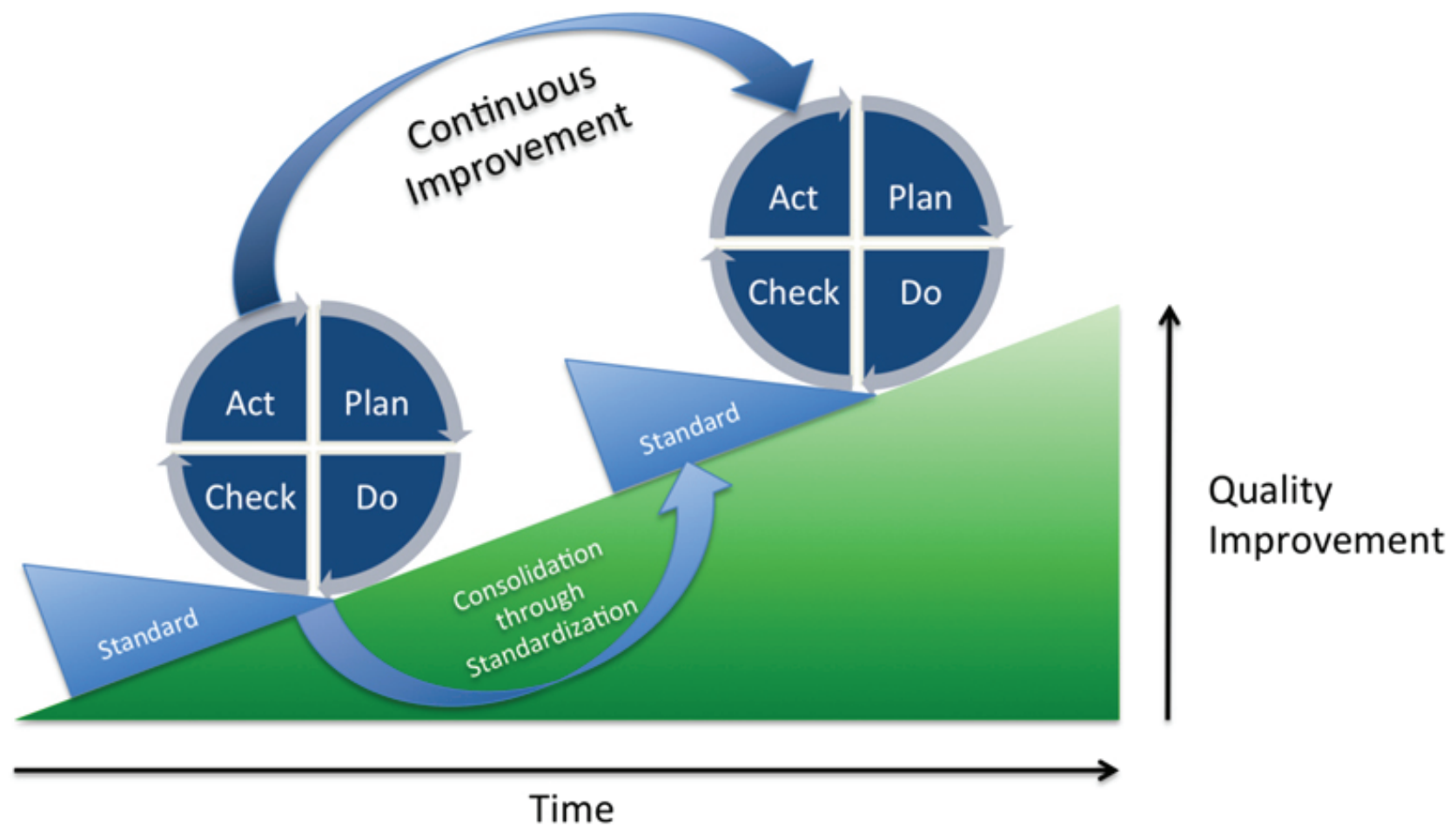

Figure 2: Principle of continuous impromevent and increasing of quality

At the same time such identification processes and their relationships can be clearly seen for each process as it is meaningful, that is whether there is a need for such activity.

For success in the functioning of the quality system of great importance is the commitment and support of top management of the organization. But it is not enough to make the system work and it is necessary to engage all of the organizational structure, to the last of the perpetrator. To make this possible, the standard insists that all activities that are implemented within the organization clearly define the duties and responsibilities of each employee who participates in them. So clearly defined obligations and responsibilities make the business of the organization facilitated.

In order to properly benefit from implementing QMS, it is necessary to obtain the final outcome of the implementation of such a system in such a way that it does not represent a major burden for the organization and perceived as an additional requirement to all employees, and also for the top management, but should achieve an approach that will ensure that the quality system is implemented as a successful tool, well recognized and defined procedures business activities in an organization that is the subject of implementation, and also manages the overall operations of the entire organization.
Some of benefits for organization from quality management implementation are:

- Providing of effective management processes for top management;

- Defining the duties and responsibilities for all structural levels in organization;

- Increase of awareness regarding to quality all over organization;

- Influence on better comunication between employees, as well as internal and external;

- Recognition of requirements and expectation of clients, which provides increase in clients satisfaction;

- Improvment of profit and credibility of organization;

- The most important are benefits for clients, i.e. benefits for end-users:

- Guaranteed level of quality product/provided services;

- Respect of defined terms and deadlines;

- Precise defined procedures in case of complaints; [01, 02]. 


\section{APPLICATION OF SYSTEM DOCUMENTATION OF QUALITY MANAGEMENT SYSTEM IN ORGANIZATION - LAGERMAX AED DOO}

Furthermore, the example will be presented of some of the most important documents adopted by quality systems, methods of their application and potential benefits from the use of this documentation.

In the first place in order to ensure continuous improvement in Lagermax AED doo organization, as one of the requirements of the quality system, it is necessary to establish a way for its implementation. After defining and identification of the key processes in the Lagermax AED doo organization and implementation, to ensure their proper and undisturbed operation, it is necessary to define the way to react in case of identification of incurred nonconformities, or in the case of detecting potential conflicts. The way to react when detecting incurred non-conformities or potential non-conformities is to take appropriate corrective and preventive measures.

It is important to note that the nonconformities are unfulfilled requirements of standard deviation or absence of one or more quality characteristics, including characteristics of the safety function, or elements of the system of quality systems / environmental protection system in relation to specified requirements.

Corrective and preventive measures are steps of cycle for improvement of functionality of management system.

In case of organization such as Lagermax AED doo, need for corrective actions exist:

1. When internal nonconformity occures (of services or some of management system elements) and can be identified based on different indicators (data information) such as:

- Reports about internal audit;

- Reports about external audit;

- Reconsideration of management system by top management;

- Usual activities during the work processes;

- Controlling of temperature through appropriate measuring devices, i.e. monitoring methods of CCP etc.;

2. Through external sources such as:

- Complaints of service users,

- Requirements for the respect of guarantees,

- Problems with suppliers,
- Complaints of the local community, inspection, i.e. some of the interested parties, etc.

Preventive action is intended for averting occurrence of potential nonconformity which can have negative influence on business results of organization. Examples of databases in organization Lagermax AED from which needs may arise for preventive actions are:

- Results of statistical management processes;

- Suggestions of producer for machine services and reconditioning of facilities;

- Monitoring of capacity utilization;

- Results of market analyses and clients behavior;

- Monitoring of the location states and processes, etc;

Each employee in Lagermax AED doo who determine problem during the usual work activities (nonconformity) addresses the nearest superior and explains the problem. Duty of the superior is to note information about nonconformity on record called "cardboard of corrective and preventive actions", and deliver cardboard of corrective and preventive actions to quality management representative.

Beside this way of nonconformity occur, it is possible to identify nonconformity during: internal audit, external audit, reconsideration of management system or by external sources.

Usually Lagermax AED pay special attention to the segment of the quality management system and way of reacting when information on nonconformity is obtained from external sources. Thus, if the source of data on external nonconformities (objections and complaints from customers, demands for respect of guarantees, problems with suppliers, objections of interested parties, etc ...) duty of the manager of organizational part whom it is addressed such a document is to, on the basis of received documentation, records information about your conflicting record card corrective and preventive actions and subsequently track delivery management representative who will take appropriate measures for improvement.

Manager of the organizational part in which nonconformities were identified performs analysis which will determine the cause of the problem. In case that for resolve is necessary to define such corrective/preventive actions which exceed jurisdiction of manager of organizational part, 
in defining of corrective and preventive actions also includes Director.

Fulfillment of performed actions will control the way that manager of organizational part, where nonconformity is identified, monitors over performed actions and provides necessary actions to be performed.

If problem is related to clients dissatisfaction or interested parties (local community, inspection, third parties), responsible manager maintains contact with client during the performing of the action.

To get constant effective level of quality in aspect of delivered services, Lagermax AED doo forms special process to monitor client's satisfaction. Procedure tool which is in use for that purposes, and which is suggested by requirements of standard ISO 9001, is defining and distribution of questionnaires.

Surveying is done for all key clients in period of half year, with possibility to do questionnaires for some of clients more frequently which is evaluated by quality management representative. After receiving of filled up questionnaires, quality management representative performs evaluation of questionnaires. Thus provides appropriate feedback regarding the clients satisfaction and where it is necessary to take appropriate actions.

One more principle which is adopted by Lagermax AED doo, suggested by requirements of ISO 9001 standard is process for management of nonconformity product/service and adoption of system approach for resolving possible complaints.

Nonconformity product/service is every product/ service which is in warehouse, and that does not corresponds to required quality criteria (damage due to transportation or unconditioned storage, expiration date, breach of contract obligations, disregard modes and procedures, etc.) and as such is inadequate for further use or distribution).

In case of identification of nonconformity services determination of their cause is perform and they are removed according to already adopted way for corrective and preventive actions which were discussed earlier.

Permanent control of products, performed by employees within the areas set aside for that, upon reception of the goods and further until the products are stored on those premises. Special attention is given to the expiration dates of food products.

If there are complaints from clients, complaints admission is performed, a reclamation record is formed which is forwarded to quality management representative that adequately responds by taking appropriate actions.

\section{CONCLUSION}

Lagermax AED recognizes quality as a great resource. In the first place, the top management ia aware of varying market and in order to preventively respond to increasingly stringent customer demands, implementation of quality management systems is seen as a good way to meet these requirements. Another reason for the need of implementation is the realization of the necessary competitiveness in the market. Despite the fact that orientation towards quality can carry with them the risk of accepting this method of operations of the staff, it was concluded that a much higher risk of losing suitable places in the market. Implementation of ISO 9001 fundamentally changes the concept so that all employees are directed to the short-term to long-term profit-seeking. Teamwork and understanding of responsibilities leads to the realization of almost all the benefits that an organization can have the logistics of implementing the quality management system, such as guaranteed quality of products / services provided, clearly recognizing the needs and expectations of the users, thus providing greater customer satisfaction, improved profit organizations, etc. and credibility. How would I implemented the system properly maintained is necessary to conduct constant review and take appropriate steps to constant improvements and the fact that in the end should not be omitted.

\section{REFERENCES}

1) Vasić, M., Stanojević, N, Stanojević, D. (2014): Strategijsko upravljanje kvalitetom u turističkim preduzećima, 41. NacionaIna konferencija o kvalitetu (FQ2014-festival kvaliteta);

2) Stevanović, I., Stanojević, D., Nedić, A. (2013): "Setting the after sales process and quality control at car dealerships to the purpose of increasing clients' satisfaction", Journal of Applied Engineering Science (Istraživanja i projektovanja za privredu), No. 2, Vol. 11, pp. 81-88; 
3) Dimitrijević, M., Vasić, M., Stanojević, D. (2014): Sistem kvaliteta u autoindustriji: slučaj autokuća Škoda i Reno, Časopis kvalitet i izvrnost (9-10/2014);

4) Vasić, M., Dimitrijevic, M., Spasojević, I.
(2013): Benefiti koje donose ISO standardi, Siimppozijum IIPP;

Paper sent to revision: 02.02.2015.

Paper ready for publication: 15.02.2015. 